\title{
Patterns of Individual Cell Growth in Marine Centric Diatoms
}

\author{
By ROBERT J. OLSON,${ }^{*} \dagger$ CARL WATRAS $\ddagger$ AND SALLIE W. CHISHOLM \\ Ralph M. Parsons Laboratory 48-425, Massachusetts Institute of Technology, Cambridge, \\ Massachusetts 02139, USA
}

(Received 1 August 1985 ; revised 27 November 1985)

\begin{abstract}
Rates of cell volume increase in individuals of five genera of centric marine diatoms were measured using time-lapse video microscopy. In continuous light, size increased continuously in Thalassiosira weissflogii and Lauderia borealis, while steps were observed during the growth of Stephanopyxis turris, Biddulphia aurita and Coscinodiscus sp. In the latter three species, the duration of the periods of no growth were well correlated with the generation time for individual cells. When the species exhibiting continuous growth in constant light were grown in a light/dark cycle of $12: 12 \mathrm{~h}$, the rate of size increase during the dark period was on average slower than during the light. Behaviour of individual cells was highly variable, however, and in $L$. borealis appeared to be related to the previous light history of each cell. The results suggest a regulatory coupling between the cell cycle and the time evolution of cell volume.
\end{abstract}

\section{INTRODUCTION}

The two most distinctive processes of the eukaryotic cell cycle are DNA replication and the doubling of cell mass or volume. The timing of DNA replication within the cell cycle (the S phase) has been extensively studied in many types of cells (Mitchison, 1971; Pardee et al., 1978) including phytoplankton (Puiseaux-Dao, 1981; Olson et al., 1983; Yentsch et al., 1983) and remains the most definitive marker of cell cycle progression. Comparatively little is known, however, about the temporal evolution of cell volume increase as cells progress through their cycles towards mitosis. Some progress in this regard has been made in studies of bacterial cells (e.g. see Krasnow, 1978; Koch \& Higgins, 1982; Kubitschek \& Woldringh, 1983) in which the increase in volume over the cell cycle (as inferred from the distribution of cellular properties in steady state cultures) is most often exponential with time. In contrast, yeast cells have been shown to have discontinuous growth between mitoses (Lindegren \& Haddad, 1953; Berg \& Ljunggren, 1982), and the achievement of a critical size has been established as a trigger for cell cycle progression in this group (Fantes, 1977; Hartwell \& Unger, 1977; Wheals, 1982).

To date, our understanding of the growth of individual diatom cells (as distinct from the process of mitosis) comes from three main sources: (1) time-lapse cinematography, (2) inferences from studies of the ultrastructure of preserved cells, and (3) sequential measurements of average cell volume in phased or synchronized cultures. The first two types of studies have revealed the sequence of events in the formation of new silica frustule components (Round, 1972; Crawford, 1981; Volcani, 1981) and morphological changes during cytokinesis (Eppley et al., 1967), and have shown that cell elongation occurs through formation of additional girdle (or intercalary) bands and/or by longitudinal sliding of the hypotheca and epitheca with respect to one another. The third type of study reveals very general information about cell growth patterns, but the behaviour of individual cells is obscured by the averaging process inherent in population studies (Chisholm et al., 1980). We have learned from this approach, however, that cells of the

† Present address: Biology Department, Woods Hole Oceanographic Institution, Woods Hole, MA 02543, USA.

$\ddagger$ Present address: Trout Lake Field Station, University of Wisconsin, Boulder Junction, WI 54512, USA. 
diatom Thalassiosira weissflogii continue to increase in size (at a reduced rate) during the dark period of a light/dark cycle (Chisholm \& Costello, 1980). In contrast, cell size does not increase in the dark in the coccolithophore Hymenomonas carterae (Olson \& Chisholm, 1983) and the dinoflagellate Amphidinium carteri (unpublished data).

Both temporal patterns of cell size increase and variations between individual cells can be investigated by time-lapse microphotography of growing cells. This approach has been used to study growth in individual bacteria (see reviews by Daneo-Moore \& Shockman, 1977; Sargent, 1978) and yeasts (Mitchison, 1957; Berg \& Ljunggren, 1982), but similar observations have not been made for phytoplankton. We have used a time-lapse video recording system to measure increases in cell length over time in five genera of centric diatoms grown either in continuous light or in light/dark cycles. The geometry and growth mechanisms of these cells (rigid cylinders which elongate but do not change in diameter between divisions) allow us to infer cell volume changes from the changes in length, thus minimizing measurement error and cell orientation problems. In this regard, planktonic diatoms are an ideal system for the study of cell size changes over the cell cycle.

\section{METHODS}

Organisms and growth conditions. Cultures of Thalassiosira weissfogii Grun. (clone Actin), Biddulphia aurita (Lyngb.) Bréb., Coscinodiscus sp. and Stephanopyxis turris (Grev. \& Arn.) Ralfs were obtained from R. R. L. Guillard (Bigelow Laboratories, W. Booth Bay Harbor, Me, USA). Lauderia borealis Gran (clone Laud 14) was obtained from the Food Chain Research Group culture collection (J. Jordan, Scripps Institution of Oceanography, La Jolla, Calif., USA). T. weissflogii and $B$. aurita are about $10 \mu \mathrm{m}$ in diameter and $15-30 \mu \mathrm{m}$ in length; these species, and the much larger Coscinodiscus sp. (diameter about $200 \mu \mathrm{m}$ and length $30-60 \mu \mathrm{m}$ ) do not form chains. L. borealis (diameter $25 \mu \mathrm{m}$, length 50-100 $\mathrm{m}$ ) grows in relatively fragile chains of up to a few cells, while $S$. turris (diameter $50 \mu \mathrm{m}$, length $75-150 \mu \mathrm{m}$ ) grows in long chains. Cells were grown in autoclaved seawater enriched with nitrate, phosphate, silicate, trace metals and vitamins according to the 'f/2' formulation of Guillard (1975). Stock cultures were maintained in continuous light from Cool-White fluorescent bulbs $\left(100 \mu \mathrm{E} \mathrm{m} \mathrm{m}^{-2} \mathrm{~s}^{-1}\right.$, measured with a Licor quantum meter with a flat plate collector). Cultures to be used in light/dark cycle experiments were grown for at least 1 week before the experiments in light/dark cycles of $12: 12 \mathrm{~h}$; the timing of light and dark phases were the same during the adaptation period and the experiments. Growth of stock cultures was monitored by measuring in vivo chlorophyll fluorescence with a Turner Designs fluorometer. Cultures were transferred to fresh medium before each experiment and transferred during the period of exponentially increasing fluorescence into fresh medium in $0.1 \mathrm{ml}$ Palmer-Maloney chambers ( $T$. weissflogii and $B$. aurita), or $1 \mathrm{ml}$ settling chambers (Coscinodiscus sp., S. turris and L. borealis) for the experiments.

Time-lapse video recording. The video monitoring system for all but one species consisted of a Wild inverted phase-contrast microscope coupled to a time-lapse video tape recording system (Panasonic NV 8030) operated in single-shot mode using a digital timer. $S$. turris, because of its large size, was examined with a Bausch $\&$ Lomb dissecting microscope coupled to the same video recorder. Temperature was maintained at $20^{\circ} \mathrm{C}$ by enclosing the microscope and video camera in a wooden chamber cooled by forced-air circulation. Light for growth (100$150 \mu \mathrm{E} \mathrm{m}^{-2} \mathrm{~s}^{-1}$ ) was supplied separately from the microscope light source by a tungsten bulb microscope illuminator fitted with glass fibre optics (model 375A, Dyonics, Andover, Mass., USA). Maximum emission from this combination, as from Cool-White fluorescent tubes (Duro-Test Corp., North Bergen, NJ, USA), was between 500 and $600 \mathrm{~nm}$; emission from the tungsten bulb at longer wavelengths, however, was higher than that from the fluorescent tubes.

Most experiments were done under continuous illumination; measurements of growth of $L$. borealis and of $T$. weissflogii were made under both continuous light and a light/dark cycle of $12: 12 \mathrm{~h}$. Video recordings during the dark interval were made using only the IR portion of the microscope illumination (by the use of Wratten filter no. 87 , which has a lower wavelength cutoff at $750 \mathrm{~nm}$ ). A timer was used to control the light supply so that light was turned on only for the time necessary to record a single frame (about $2 \mathrm{~s}$ ), and the video images were recorded at the rate of one frame $\min ^{-1}$.

Length measurements. Measurements of cell length were made directly from the video monitor screen at hourly intervals using a digital micrometer. The measurements were made on 6-23 cells in each experiment, selected at random from the cells which remained in the field of view for a complete generation. Since diameter does not increase with growth, cell length is directly proportional to volume and the results can be presented in units of relative cell length. 


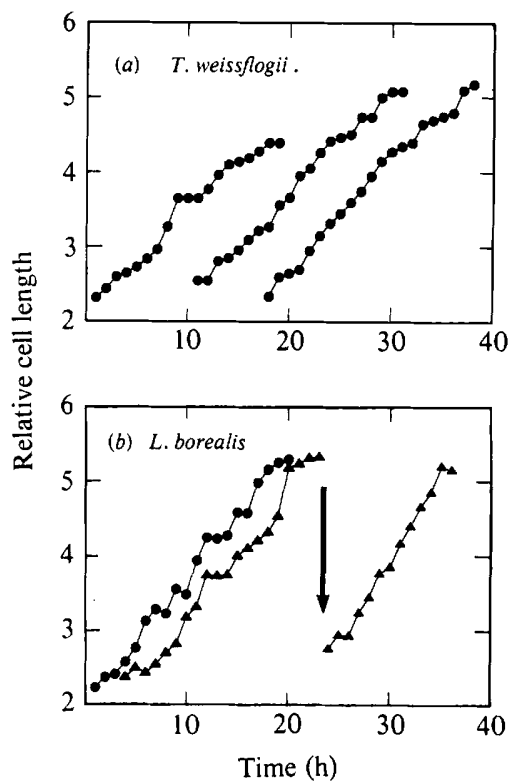

Fig. I
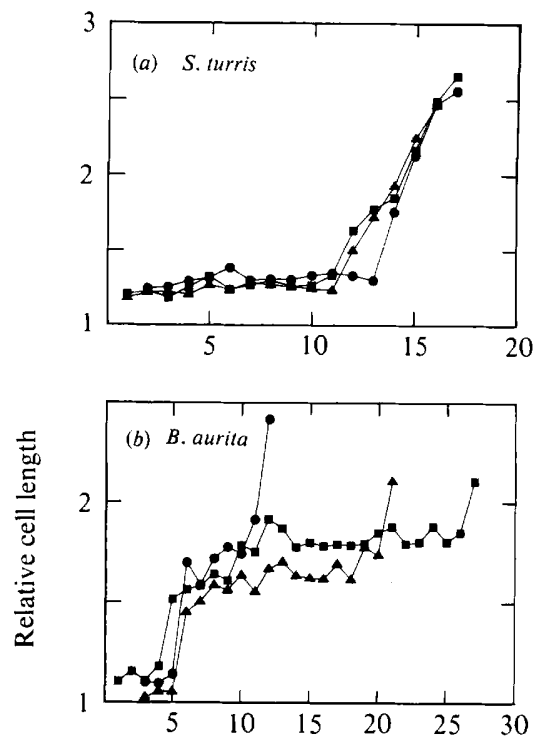

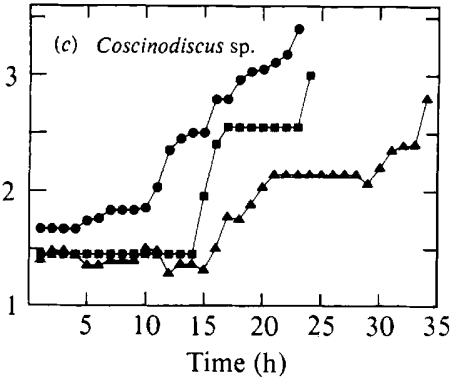

Fig. 2

Fig. 1. Change in length (=volume) as a function of time of three individual cells of $(a)$ Thalassiosira weissflogii and $(b)$ Lauderia borealis, in continuous light. Each plot begins and ends with a cell division event. The arrow in (b) marks the division of a mother cell $(\boldsymbol{\Delta})$ followed by the growth curve of one of the daughter cells. In all other cases, the cells are not from successive generations.

Fig. 2. Change in length (=volume) as a function of time of three individual cells $(\mathbf{\square}, \mathbf{O}, \mathbf{\Delta})$ of $(a)$ Stephanopyxis turris, $(b)$ Biddulphia aurita and $(c)$ Coscinodiscus sp., in continuous light. Each plot begins and ends with a cell division event but the cells do not represent successive generations.

\section{RESULTS}

\section{Growth in constant light}

The growth patterns of representative cells of the five species grown in constant light revealed major differences between species in the time course of size increase (Figs 1 and 2). Although there was some variability from cell to cell within each species (due at least partly to measurement error and occasional tipping of cells away from the horizontal), it is clear that the species fall into two general groups in terms of their growth patterns. In $T$. weissflogii and $L$. borealis the increase in cell size was continuous and linear with time from one division to the next (Fig. 1). In contrast, cells of $S$. turris, B. aurita and Coscinodiscus sp. all showed definite periods in the cell cycle in which size did not increase (Fig. 2).

$S$. turris was the clearest example of what we call the 'step' pattern: all cell growth occurred in the 6-10 h just before division, even when the interdivision time was as long as $39 \mathrm{~h}$ (Fig. $2 a$ ). Many of the $S$. turris cells in a given chain divided within minutes of each other (even though they had been growing in constant light and nutrient-replete conditions for at least several days 


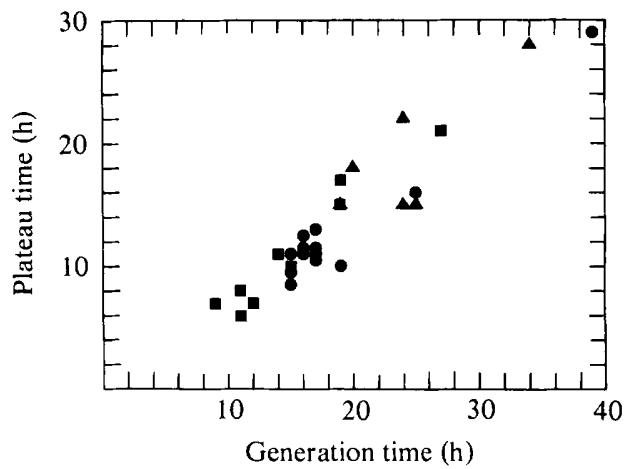

Fig. 3

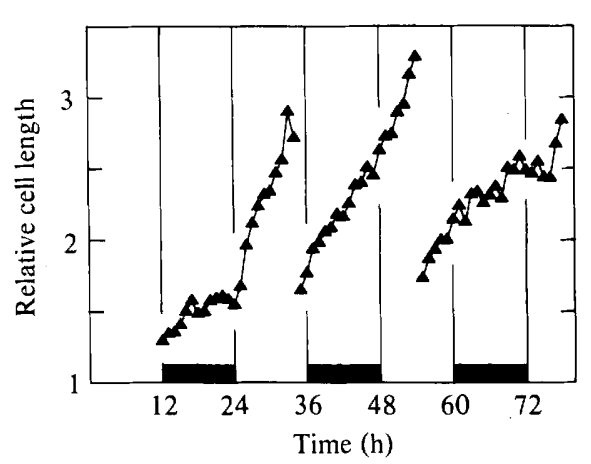

Fig. 4

Fig. 3. Time spent in 'plateau' or non-growing stages of the cell cycle as a function of the generation time in the three species shown in Fig. $2 ; B$. aurita $(\mathbf{\Delta})$, Coscinodiscus sp. ( $\square$ ) and $S$. turris (O). The duration of the plateau stage was determined subjectively from the time course for each cell. The correlation between the plateau time and the generation time of all the cells was significant $\left(r^{2}=0 \cdot 80\right)$.

Fig. 4. Growth patterns of three successive generations of $T$. weissflogii grown in a light/dark cycle of $12: 12 \mathrm{~h}$. The shaded areas indicate dark periods.

before the experiments and thus should not have been synchronized by external entraining agents). This tight synchrony may be responsible for the consistency of the growth pattern from cell to cell in a given chain. B. aurita and Coscinodiscus sp., which are not chain-forming, had more variable patterns: these species generally showed an initial lag in growth after division, a plateau at about $80 \%$ of final cell size, and a final burst of growth immediately before division (Fig. 2b,c). Similar late growth spurts have been documented in the centric diatom Melosira moniliformis (Crawford, 1981). Differences in generation times between individual cells of the species exhibiting a plateau were well correlated with differences in the durations of the plateau periods (Fig. 3). This suggests a regulatory coupling between the cell cycle and the time evolution of volume increase (see below).

\section{Growth in light/dark cycles}

$T$. weissflogii and $L$. borealis, which exhibited a continuous increase in size in constant light, were also examined under a light/dark cycle of $12: 12 \mathrm{~h}$ (Figs 4 and 5). Both species could increase their cell size during the dark, although at a slower rate than in the light. $T$. weissflogii cells showed great variability in the rate of size increase in the dark. As exemplified by the three time courses shown in Fig. 4, some cells virtually stopped growing, others grew at a reduced rate, and a few grew nearly as fast in darkness as in light. The mean rate of increase of cell size in darkness, however, was significantly less than that in the light $(P<0.005, t$ test for 2 means) when responses of 12 cells were averaged; the mean rate (in arbitrary units of length per unit of time) in darkness was 33.2 ( $n$, the number of growth periods in darkness during the 12 cell lifetimes, was $11, \mathrm{SD}=15.5)$ while that in the light was $80.9(n=15, \mathrm{SD}=22.9)$.

$L$. borealis responded to the light/dark cycle similarly to $T$. weissflogii in that the mean growth rate in darkness was also significantly lower than that in the light $(P<0.005, t$ test for 2 means); for a sample of 23 cells, the mean rate in darkness was $12.4(n=19, \mathrm{SD}=11 \cdot 2)$ while that in the light was $34.9(n=23$, SD $=13.0)$. In $L$. borealis, however, there appear to be two distinct patterns of growth under light/dark cycles that result in this 'average' relationship. In the first pattern, increases in cell size occurred mainly during the light period. Cells 'born' at the light-todark transition (Fig. 5a) grew very slowly (if at all) during the dark period and doubled in size and divided during the next light period; cells born near the beginning of the light period either doubled in size and divided near the light-to-dark transition (Fig. $5 b$ ) or, if they grew more slowly, resumed growth and divided only in the next light period (Fig. $5 c$ ). In contrast, cells that were born several hours before the end of the light period continued to increase in size in the dark and divided at the end of the dark period (Fig. $5 d$ ). 


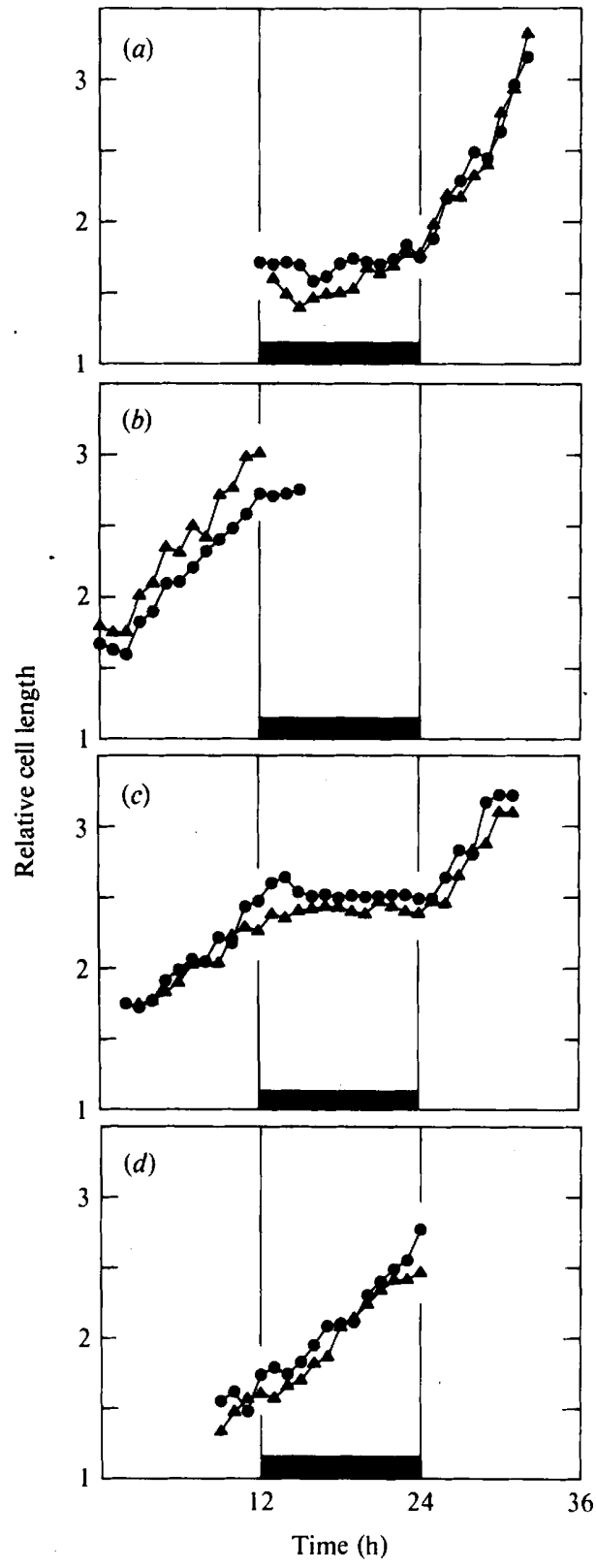

Fig. 5. Growth patterns of $L$. borealis cells born at different times in a light/dark cycle. Patterns from two representative cells $(\boldsymbol{\Delta}, \boldsymbol{O})$ of each type are illustrated. Shaded areas represent the dark period. (a) Cells born at the light-to-dark transition, which did not grow during the dark. (b) Cells born at the dark-to-light transition, which divided at the end of the light period or beginning of the next dark period. (c) Cells born early in the light period, which did not grow in the dark and did not divide until the next light period. (d) Cells born several hours before the end of a light period, which continued growing through the dark period and divided before the next light period.

\section{DISCUSSION}

In cells that do not grow continuously throughout the cell cycle, the duration of the nongrowing interval (the plateau phase) was directly proportional to the generation time of the cell. This phenomenon is in a sense analogous to the $G_{1}$ extension with increasing generation times observed in many cell types, including yeasts (Slater et al., 1977; Johnston et al., 1980; Singer \& Johnston, 1981) and both eukaryotic and prokaryotic micro-algae (Chisholm et al., 1986), and suggests that cell size increase may be coupled to the DNA cell cycle controls. The relative constancy of the duration of the growth phase over a range of cell generation times in these species implies that 'normal growth' proceeds after some threshold has been achieved; this is 
similar to the concepts of 'arrest' and 'transition' points demonstrated in the cell cycles of many organisms, including phytoplankton (Yanishevsky \& Stein, 1981; Spudich \& Sager, 1980; Chisholm et al., 1984; Vaulot, 1985). It would be interesting to place precisely the 'plateau' phase within the cell cycle using videomicroscopy and microfluorometry of cells stained with a vital fluorescent DNA probe such as Hoechst 33342.

The common observation of relatively constant accumulation of cell material over the cell cycle (John et al., 1982; Mitchison, 1984) suggests that the steps in cell growth observed in constant light in three of our experimental species are more probably due to vacuolar expansion than changes in biosynthetic rates. The process might be likened to that of cell elongation in higher plants, which occurs via a hormone-mediated softening of the cell wall followed by tugordriven expansion (Raven et al., 1976). The silica frustule of the diatom cannot be softened, but longitudinal sliding of the two halves of the frustule with respect to one another (Round, 1972) accomplishes the same end.

Another essential component of cell growth in diatoms is the growth of existing girdle bands (or formation of new intercalary bands) that push the two halves of the frustule apart; this mode of growth can be continuous throughout the cell cycle (Round, 1972) and might be expected to result in more continuous size increases. Although speculations that these growth modes might be responsible for the patterns we observed have no supporting evidence, they do suggest a set of testable hypotheses that might reveal links between ultrastructure and the process of growth in these organisms.

The patterns of growth in darkness of the two species that showed continuous growth in constant light do not lend themselves to a mechanistic explanation. Those patterns exhibited by L. borealis, in which the growth rate during the dark period is a function of the amount of light exposure a cell receives during the previous light period, indicate clearly that past history is an important regulator of the response. It appears that a cell must have experienced some light exposure since its birth in order to increase in size during the dark. On the other hand, cells which have undergone a significant proportion of their total size increase in the light appear to stop growing in the dark. It is also interesting that although both $T$. weissflogii and $L$. borealis were grown in light/dark cycles of $12: 12 \mathrm{~h}$ for several days before the video measurements, dividing cells were observed in all phases of the photocycle. This weak phasing of cell division by light/dark cycles is in agreement with the results of cyclostat studies (Chisholm \& Costello, 1980) and the division patterns in diatoms in general (Nelson \& Brand, 1979; Chisholm et al., 1980).

One of our original goals in this research was to study the distribution of generation times in clonal diatom populations. Preliminary data (Chisholm et al., 1980) suggested that the distributions might be quantized in this group of species, as observed in mammalian cell lines (Klevecz, 1976). We hypothesized that such a distribution could help explain the rather unorthodox division patterns expressed by diatom populations in light/dark cycles. The combined results of all our video recordings of generation times in clonal diatom populations have not revealed any consistent patterns of generation time distribution. We believe this is due to the unusual degree of cell-to-cell variability in generation times in this group (Chisholm et al., 1980), which demands an unusually large number of cell generation time measurements for statistical resolution.

These observations of cell growth patterns of individual diatom cells, though purely descriptive, may be significant in several ways. The demonstration that a variety of patterns of size increase over the cell cycle are possible, depending on the species and environmental conditions, raises new questions regarding the relationship between the cell growth cycle and the DNA cycle and also the underlying physical mechanisms of diatom cell growth. The results also suggest that diatoms, because of the variety of patterns displayed and ease of measurement, could provide a useful new model system for the study of size control of the cell cycle in plant cells.

This work was supported in part by NSF Grants OCE-7708999, OCE-8118475 and OCE-8121270, OCE8316616 and by the Dougherty Professorship of Ocean Utilization awarded to S.W.C.

We thank T. McNeil and M. Gard for technical assistance, and Jane Marsh for typing the manuscript. 


\section{REFERENCES}

BERG, T. G. O. \& LJUNGGREN, B. (1982). The rate of growth of a single yeast cell. Biotechnology and Bioengineering 24, 2739-2741.

Chisholm, W. W. \& Costello, J. C. (1980). Influence of environmental factors and population composition on the timing of cell division in Thalassiosira fluviatilis (Bacillariophyceae) grown on light/dark cycles. Journal of Phycology 16, 375-383.

Chisholm, S. W., Morel, F. M. M. \& Slocum, W. S. (1980). The phasing and distribution of cell division cycles in marine diatoms. In Primary Productivity in the Sea, pp. 281-300. Edited by P. Falkowski. New York: Plenum.

Chisholm, S. W., Vaulot, D. \& Olson, R. J. (1984). Cell cycle controls in phytoplankton: comparative physiology and ecology. In Cell Cycle Clocks, pp. 365-394. Edited by L. N. Edmunds. New York: Marcel Dekker.

Chisholm, S. W., Olson, R. J. \& ARmbrust, E. V. (1986). The individual cell in phytoplankton ecology: cell cycles and applications of flow cytometry. In Physiological Ecology of Photosynthetic Picoplankton in the Ocean. Edited by T. Platt. Ottawa: Canadian Bulletin of Fisheries and Aquatic Science (in the Press).

CRAWfORd, R. M. (1981). The siliceous components of the diatom cell wall and their morphological variation. In Silicon and Siliceous Structures in Biological Systems, pp. 129-156. Edited by T. L. Simpson \& B. E. Volcani. New York: Springer-Verlag.

Daneo-Moore, L. \& Shockman, G. D. (1977). The bacterial cell surface in growth and division. Cell Surface Reviews 4, 597-715.

Eppley, R. W., Holmes, R. W. \& PaAsche, E. (1967). Periodicity in cell division and physiological behavior of Ditylum brightwellii, a marine plankton diatom, during growth in light/dark cycles. Archiv für Mikrobiologie 55, 66-80.

FANTES, P. A. (1977). Control of cell size and cycle time in Schizosaccharomyces pombe. Journal of Cell Science 24, 51-67.

GuillaRD, R. R. L. (1975). Culture of phytoplankton for feeding marine invertebrates. In Culture of Marine Invertebrate Animals, pp. 29-60. Edited by W. L. Smith \& M. H. Chaney. New York: Plenum.

HartWell, L. H. \& UNGER, M. W. (1977). Unequal division in Saccharomyces cerevisiae and its implications for the control of cell division. Journal of Cell Biology 75, 422-435.

John, P. C. L., LAMB, C. A., McGookin, R., ORR, B. \& Rollins, M. J. (1982). Poly(A) ${ }^{+}$RNA populations, polypeptide synthesis and macromolecule accumulation in the cell cycle of the eukaryote Chlorella: Journal of Cell Science 55, 51-67.

Johnston, G. C., Singer, R. A., Sharrow, S. O. \& SLATER, M. L. (1980). Cell division in the yeast Saccharomyces cerevisiae growing at different rates. Journal of General Microbiology 118, 479-484.

KLEVECZ, R. R. (1976). Quantized generation time in mammalian cells as an expression of the cellular clock. Proceedings of the National Academy of Sciences of the United States of America 73, 40124016.

KoCH, A. L. \& Higgins, M. L. (1982). Cell cycle dynamics inferred from the static properties of cells in balanced growth. Journal of General Microbiology 128, 2877-2892.

KRASNOW, R. A. (1978). Mass, length and growth rate in single cells. Journal of Theoretical Biology 72, 659699.

Kubitschek, H. E. \& Woldringh, C. L. (1983). Cell elongation and division probability during the Escherichia coli growth cycle. Journal of Bacteriology 153, 1379-1387.

Lindegren, C. C. \& HAdDAd, S. A. (1953). The control of nuclear and cytoplasmic synthesis by the nucleocytoplasmic ratio in Saccharomyces. Experimental Cell Research 5, 549-550.

Mitchison, J. M. (1957). The growth of single cells. Experimental Cell Research 13, 244-262.

Mrtchison, J. M. (1971). The Biology of the Cell Cycle. Cambridge: Cambridge University Press.

Mitchison, J. M. (1984). Dissociation of cell cycle events. In Cell Cycle Clocks, pp. 163-171. Edited by L. E. Edmunds. New York: Marcel Dekker.

Nelson, D. M. \& BRAND, L. F. (1979). Cell division periodicity in 13 species of marine phytoplankton on a light/dark cycle. Journal of Phycology 15, 6775.

OlsON, R. J. \& ChISHOLM, S. W. (1983). Effects of photocycles and periodic ammonium supply on three marine phytoplankton. I. Cell division patterns. Journal of Phycology 19, 522-528.

Olson, R. J., Frankel, S. L., Chisholm, S. W. \& Shapiro, H. M. (1983). An inexpensive flow cytometer for the analysis of fluorescence signals in phytoplankton: chlorophyll and DNA distributions. Journal of Experimental Marine Biology and Ecology 68, 129-144.

Pardee, A. B., Dubron, R., Hamlin, J. L. \& KLEVTSIEN, R. F. (1978). Animal cell cycle. Annual Review of Biochemistry 47, 715-750.

Puiseaux-DaO, S. (1981). Cell cycle events in unicellular algae. In Physiological Bases of Phytoplankton Ecology, pp. 130-149. Edited by T. Platt. Ottawa : Canadian Bulletin of Fisheries and Aquatic Science.

Raven, P. H., Evert, R. F. \& Curtis, H. (1976). The Biology of Plants. New York: Worth.

Round, F. E. (1972). The formation of girdle, intercalary bands and septa in diatoms. Nova Hedwigia 23, 449-463.

SARGENT, M. G. (1978). Surface extension and the cell cycle in procaryotes. Advances in Microbial Physiology 18, 105-176.

SingER, R. A. \& Johnston, G. C. (1981). Nature of the G1 phase of the yeast Saccharomyces cerevisiae. Proceedings of the National Academy of Sciences of the United States of America 78, 3030-3033.

Slater, M. L., Sharrow, S. O. \& Gart, J. J. (1977). Cell cycle of Saccharomyces cerevisiae in populations growing at different rates. Proceedings of the National Academy of Sciences of the United States of America 74, 3850-3854.

SPudich, J. L. \& SAGER, R. (1980). Regulation of the Chlamydomonas cell cycle by light and dark. Journal of Cell Biology 85, 136-145.

Vaulot, D. (1985). Cell cycle controls in marine phytoplankton. $\mathrm{PhD}$ thesis, Massachusetts Institute of Technology, Cambridge, Mass., USA.

VOLCANI, B. E. (1981). Cell wall formation in diatoms: 
morphogenesis and biochemistry. In Silica and Siliceous Structures in Biological Systems, pp. 157200. Edited by T. L. Simpson \& B. E. Volcani. New York: Springer-Verlag.

WHEALS, A. E. (1982). Size control models of Saccharomyces cerevisiae cell proliferation. Molecular and Cellular Biology 2, 361-368.

Yanishevsky, R. M. \& Stein, G. H. (1981). Cell cycle regulation in eukaryotic cells. International Review of Cytology 69, 223-259.

Yentsch, C. M., Mague, F. M., Horan, P. K. \& MUIRHEAD, K. (1983). Flow cytometric DNA determinations on individual cells of the dinoflagellate Gonyaulax tamarensis var. excavata. Journal of Experimental Marine Biology and Ecology 67, 175183. 